\title{
Effect of Competence, Satisfaction and Discipline on Performance of Employees in the Office of Women Empowerment and Family Planning of West Papua
}

\author{
Suyitno ${ }^{1}$ \\ ${ }^{1}$ Management Department, Indonesia Economic College, Malang, Indonesia \\ Correspondence: Suyitno, Indonesia Economic Collge, Jl. Mega Mendung No. 1-9 Malang, Indonesia. E-mail: \\ dryitno@gmail.com
}

Received: March 6, 2017

Accepted: March 29, 2017 Online Published: April 19, 2017

doi:10.5539/ass.v13n5p144

URL: https://doi.org/10.5539/ass.v13n5p144

\begin{abstract}
This study investigates the effect of competence, satisfaction, and discipline on performance of employees in the Office of Women Empowerment and Family Planning of Fak-fak West Papua. Assigning 18 respondents, this study collected data using questionnaire, interview and document and used SPSS 17.0 for analysis on multiple regression and t-test. The findings showed the significant effects existed between (1) the competence of work (X1) on the performance of employee (Y) $\mathrm{r}=0.682 ; \mathrm{p}=.011 ;(2)$ the job satisfaction (X2) with the performance of employee (Y) $r=0.241 ; p=.025$; (3) the discipline of work (X3) with the performance of employee (Y) $r=0.230$; $\mathrm{p}=.034$; and (4) the competence (X1), the job satisfaction $\left(\mathrm{X}_{2}\right)$, and the discipline (X3) to the performance employee partially or simultaneously at $\mathrm{r}=0.135$. A weak effect of competence, job satisfaction and discipline of work existed on the performance of employee.
\end{abstract}

Keywords: performance, competence, satisfaction, discipline, public services

\section{Background}

Emerging issues related to regional autonomy is seen from the competence of human resources and apparatues the Local Government has to serve the official services, public services, and developments. This way, the government apparatus has an apparent role and very important position as the motor and driving force in activities of government functions aligned to reform that demands clean government and immorality. However, many regions recognize that competence of human resources and apparatus still need to improve (Dwiyanto, 2003).

According to Steers $(1985$, p. 148) the individual performance is strongly influenced by a variety of unique personal characteristics of each individual. If a worker does not have the competence required for a particular job, or if he is not interested in the job, it is hard to believe that the level of achievement will be high. On the other hand, if management in recruiting and training workers competence and interest is in tune with the demands of work, we can expect that chances of good performance can be improved.Success in achieving the goals of organization is strongly influenced by the role and performanceemployees. The important role of employees or individuals in achieving organizational goals is that, the organization is impersonal and very rational in integration of a number of specialists who work together to achieve agreed objectives (Liliweri, 1997). Cited by Iqbal (2015) Hassan et al. (2011) assert that job satisfaction level in private banking sector and most of the employees working in private banks are satisfied with their work, management functions and job positions. Through increased work discipline and competence of employees' work, vision, mission, and goals of the organization can be achieved effectively. Discipline (Wekley \& Yukl, 2000) and competence (Simamora, 1995) are factors that affect employee performance. An increase of discipline and competence of employees can give a positive contribution to performance the organization planned earlier.

Problems contained in the Office of Women's Empowerment and Family Planning in Fak-Fak West Papua is low performance of employees. Allegedly, poor performance exsists due to low employee competencies, job satisfaction and employee discipline. The gap between what it should be (das sollen) with what is realistic (das sein) affects low performance of employees in the office.

Based on the background above, the following research questions are defined. 
a. Is there any significant relationship between the competence toward the performance of employee in the Office of Women Empowerment and Family Planning of Fakfak West Papua?

b. Is there any significant relationship between the job satisfaction toward the performance of employees in the Office of Women Empowerment and Family Planning of Fakfak West Papua?

c. Is there any significant relationship between the work discipline toward the performance of employee in the Office of Women Empowerment and Family Planning of Fakfak West Papua?

d. Is there any significant relationship between the competence, job satisfaction and discipline simultaneously toward the performance of employee in the Office of Women Empowerment and Family Planning of Fakfak West Papua?

\section{Review of Literature}

\subsection{Competence Employee}

Viewed from organizational behavior perspective, the competences and commitments are categorized as individual characteristic of organization members. Experts on organizational behavior, such as Kinicki \& Kreitner (2003) argue the concept of competence is perceived as a combination of competence and skill. Wood, Wallace and Zeffane (2001), Robbins (2007) conceive competence as a combination of talent (aptitude) and competence (ability). The competences, as a measurement tool, identify behavioral factors relevant to performance in the job and viewed as how the job is carried out. Hence, many organizations use the competency models as a part of their employee development program to appraise behavioral performance indicators together with objectives (Özçelik and Ferman, in Zaim et al., 2013 ).

Different from experts of organizational behavior, scholars on management (Koenig, 1997; Mayo, 2002), assert competence and commitment are human capital that is the employees. In support with consumer the capital and structure capital, they form intellectual capital of organization. Competence and commitment are seen as determining factors of an organization's intellectual capital, "Intellectual Capital = Competence x Commitment." Spencer and Spencer (1993) suggest that individual competences are attitudes and behaviors; it is an individual competences that are relatively stable when faced a situation in the workplace that is formed from synergy between character, self-concept, internal motivation, and capacity of contextual knowledge.

\subsection{Job Satisfaction}

Description of job satisfaction in this study refers to concepts proposed by Davis (1985) and Handoko (2005). Davis (1985) states that job satisfaction is the feeling of support or do not support self-employee that is associated with the work and individual condition. Handoko (2005) argues that job satisfaction is an emotional state that is favorable or unfavorable to which employees view their job. Manulang (2004) explains the job satisfaction is an emotional state in which employees perceive to accept or reject the remuneration given by a company or organization on the value of benefit that are desired by the employees. The employee remuneration can be in the form of "financial" or the "non-financial". Anoraga (2001) asserts that the job satisfaction is the satisfaction associated with the employee attitudes toward work itself, work situation, relations between superiors and subordinates and relationships among employees.

Variables related to job satisfaction include the achievement, advancement, job enhancement, job enrichment, and teamwork. Job satisfaction has to do with an individual's perception and evaluation of his job, and this perception is influenced by the person's unique circumstances such as needs, values, and expectations (Muindi, 2015). Luthans (1995) states that the satisfaction arises from the evaluation of an experience, or statements related to psychological problems and an expectation of what the employees earn. In addition, Wexley and Yukl (2002) define the job satisfaction simply and operational as how a worker views and feels about his job. Job satisfaction generates employees' attitudes towards their works which is based on the various aspects of his works. Specifically, job satisfaction can be explained through theory of Wexley and Yukl (2002) below.

\section{a. Incompatibility Theory}

Locke (1969) explains that the satisfaction or dissatisfaction and their aspects of work refers to the difference between what is deemed to obtain by what is "desirable". Number of "unwanted" of work characteristics is defined as the minimum amount required to meet the existing needs. A person will be satisfied if there is no difference between the desired conditions with the actual conditions. The greater the shortage and the more important things to be desired, the greater the dissatisfaction is. According to Porter (1961) the satisfaction is the difference of amount of something that "there should be" with many "what is". Similar to Locke, this conception is basically the same as "what should be". Locke views that the satisfaction has more emphasis on the equitable 
considerations and shortcomings on the needs. Determinant of many factors of work are preferred.

\section{b. Theory of Justice}

This theory has been developed by Alwi (1963), and is a variation of theory of social comparison processes. The main component of this theory is "input", "result", "comparison" and "justice and injustice" (Wexley \& Yukl, 2002). According to Moorman (1991) cited by Al-Zu'bi (2010) the organizational justice is concerned specifically with the ways in which employees determine if they have been treated fairly in their jobs and the ways in which those determinations influence other work-related variables.

\section{c. Needs Satisfying Theory}

Mangkunagara (2001) explains that theory of employee job satisfaction depends on whether or not the employee's needs are met. An employee would be satisfied if he gets what he needs. The greater the employee's needs are met, the more satisfied the employee anyway. Vice versa if the employee's needs are not met, he will feel satisfied.

\section{d. Social Groups Theory}

Mangkunagara (2001) states that theory of employee job satisfaction is not dependent on the fulfillment of course, but it much depends on the views and opinions of which the employee is considered as reference group. In essence, the view of social group or reference shall be made by an employee of benchmarks to assess themselves and their environment. Thus, the employees will feel satisfied. Davis (1985) cited by Mangkunagera (2005, p. 1) explains that the job satisfaction is related to the variables or factors that influence the individual wish, including: turnover, level of work absence, age, level jobs, and size of company organization. Gomes (2002) cited by As'ad (2004, p. 1) asserts that job satisfaction consist of: (1) opportunity to move forward, (2) job security, (3) salary, (4) company and management, (5) monitoring and supervision, (6) intrinsic factors of the job, (7) social aspect in the work, (8) working conditions, (9) communications, and (10) amenities.Job satisfaction and its factors affecting satisfaction are stated as follows:

1. Merits that deserve incentives or reimbursements should be fair and reasonable. So far, compensation or remuneration in the form of wages or salaries is satisfied, yet supporting facilities, e.g. bonuses, services and provisions are not well-planned.

2. The opportunity to step forward or promotion is identical to work that is mentally challenging. An opportunity given to employees to improve their competence or skills and participate in decision-making should be made available.

3. The atmospheres, conditions or work environment should be identical to supportive working conditions -a condition or atmosphere in the workplace.

4. Supporting co-workers should be identical to a harmonious relationship with fellow employee and sub-ordinate relationship between employees and leaders that directly contact in daily life while doing the job.

5. The job itself should be identical to job characteristics that are tailored to the job context and content of work, which should be done by an employee in performing duties imposed.

According to Misener et al. (1996) in Al_Zu'bi (2010) the job satisfaction is generally recognized as a multifaceted construct that includes employee feelings about a variety of both intrinsic and extrinsic job elements. It encompasses specific aspects of satisfaction related to pay, benefits, promotion, work conditions, supervision, organizational practices and relationships with co-workers.

\subsection{Discipline of Employee}

According to Nitisemito (1988) factors influencing the emergence of a labor discipline vary: purpose of employment and work ability, leadership exemplary, welfare, justice, inherent supervision, legal sanctions, firmness, and human relations. Labor discipline is a major factor in performing management functions. If the work discipline has been neglected, other task of work will not be well performed. Indiscipline is not merely an indication of the enthusiasm and excitement of work, but it affects the effectiveness and efficiency of achievement to gain objectives of the company. Sutrisno (2011, p. 86) suggests that discipline indicates a condition or comity that is on the employee to the company rules and regulations. Thus if the rules or regulations that exist in the company are ignored, or often violated, then the employee has a poor work discipline (Thaief et al., 2015). Discipline is a procedure to correct or punish subordinateemplyoees who break the rules and procedures.Discipline of work is essentially the nature of an employee to obey all laws in their place of work. Behavior of employee discipline is something that does not appear on its own, but needs to be formed (Simamora, 2004, p. 610). Establishment of labor discipline behavior, according Commings (1984) can be done 
in two ways:

1) Preventive dicipline

Preventive dicipline is an action to encourage workers to comply with norms and rules that a violation should not occur. The aim is to heighten awareness of workers about the wisdom and regulations of their job experience.

\section{2) Corrective discipline}

Corrective discipline is an act that follows the breach of rules. It tries to shrink further offense, so that in the future, employee behavior can comply with regulation norms. Basically, the goal of all discipline is to make someone aware to behave according to what was approved by the company, making an employee persue with a good social adjustment. However, when working, an employee can display behavior that is not discipline. Gibson et al. (1988) suggest some indicsipline employee behaviors that can be punished include:absence, inaction, leaving the workplace, stealing, sleeping while working, fighting, threatening leaders, repeating poor performance, violating rules and policies of safety, defiance of orders, treating trespass unnaturally, slowering job, refusing to cooperate with colleagues, refusing overtime work, having and using drugs while working, damaging equipment, using language or profanity, and stopping to work illegally.

\subsection{Performance Employee}

Gie (1995) argues performance is how far the task or work is done by a person or organization. Performance is measured on the basis of how much a person or organization contribues. Irawan (2000) states performance is the work that is concrete, observable, and measurable. Performance is the result of work achieved by an employee in execution of duties by size and time specified.According to Mangkunagara (2000) performance is commensurate to actual performance; it is a result of quality and quantity of work that an employee hasperformed in accordance with his responsibilities. Rue and Byars (1980) define performance as a level of achievement or "the degree of complishment".Performance indicates level of achievement of organizational goals. Through performance level of achievement can be measured and known.

Simamora (1995) defines performance as requirements to a specific job that eventually is reflected in resulted output. The output is related to result of work implementation physically or non-material. Associated with products measured in quantity, e.g. a shoe factory, cigarette, performance measurement is easy to do. Martoyo (2004) defines performance as a function of interaction between competence (ability), motivation and desires (obsession) and illustrated as $\mathrm{f}(\mathrm{A} \times \mathrm{M}$ x O). If there is inadequate fact, performance will be negatively affected. As so, motivation, competence and capability are neccessary to consider to describe and assess the performance of an employee. With high employee motivation, an individual will have high performance and vice versa, thus motivation and competence have a positive relationship.

Performance according to Benardin and Russell (1998, p. 239) is the record of outcomes resulted from job functions or specific job activities for a certain period of time. According to Wood et al. (2001, p. 114) performance is a concise measurement of quantity and quality of contribution of tasks performed by individuals or groups to work unit or organization. According Benardin \& Russell (1998) there are six primary criteria to measure performance: (1) Quality, (2) Quantity, (3) Timeliness, (4) Cost-effectiveness, (5) Need for supervision, and (6) Interpersonal impact.

\subsection{Conceptual Framework}

Based on the above theories, conceptuali framework of this study can be described as follows:

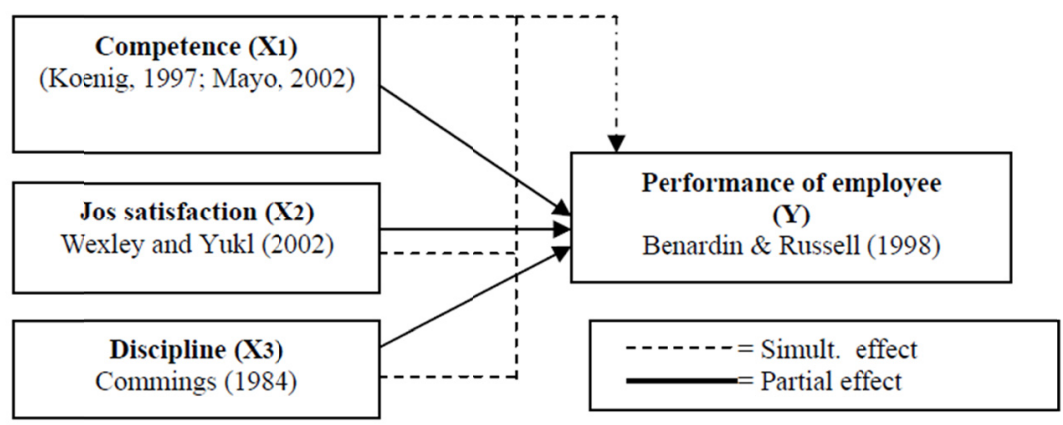

Figure 1. Conceptual Framework of this research 


\subsection{Research Hypothesis}

Based on the conceptual framework above, hypotheses of this research are formulated as follows:

a. There is any significant relationship between competence (X1) towardperformance of employee of the Office of Women Empowerment and Family Planning of Fakfak (Y).

b. There is any significant relationship between satisfaction $\left(\mathrm{X}_{2}\right)$ towardperformance of employees in the Office of Women Empowerment and Family Planning of Fakfak (Y).

c. There is any significant effect between discipline (X1) towardperformance of employees in the Office of Women Empowerment and Family Planning of Fakfak (Y).

d. There is any significant effect between discipline (X1) and satisfaction $\left(\mathrm{X}_{2}\right)$ toward performance of employees in the Office Women Empowerment and Family Planning of Fakfak (Y).

\section{Method}

This study is an explanatory research that used existing data for analysis. Independent variables of this study included: competence, job satisfaction, and work discipline. The dependent variable was competence of employees. No treatments were used in this study to manipulate participants behaviors. The study was conducted from April to June 2015 in the Office of Women Empowerment and Family Planning of Fak-fak district, West Papua, Indonesia.Participants were 18 employees who work at the Office of Women Empowerment and Family Planning of Fak-Fak. All 18 participants werewomen, aged between 30 to 50 years and had been working in the office for 10 to 15 years. Data were collected using questionnaire, interview and document analysis. To proceed in the statistical description, this study used SPPS 17.0 as a tool of analysis.

\section{Results and Discussion}

\subsection{Regression Analysis}

Once all the data from respondents were fully recapitulated, the analysis continued to using a multiple linear regression. First, all data from the questionnaire were neatly arranged in the table-entry using software MS Exel. Second, data were processed using multiple linear regression SPSS software version 17.0. Results of analyses are in Table 1.

From table 1 above a multiple linear regression equation was made as follows:

$$
\mathrm{Y}=10.4729+0,592 \mathrm{X} 10,674 \mathrm{X} 2+0,336 \mathrm{X} 3+\mathrm{e}
$$

The regression results show the direction of influence of each independent variable on dependent variable changes. Competence of employees (X1), job satisfaction (X2) and discipline (X3) have positive influences on the performance employee $(\mathrm{Y})$. This means any major increase or decrease in the independent variables will be followed by an increase or decrease in performance employee.

Table 1. Summary of multi linear regression analysis

\begin{tabular}{cccc}
\hline Variable & Coef. Reg. & Std. error & T. Stat \\
\hline Competente of employee & 0,5922 & 0,1245148 & 2.347 \\
Job satisfaction & 0,6739 & 0,4138318 & 2,178 \\
Discipline & 0,3362 & 0,1257447 & 21.247 \\
Constant & 10.4729 & 14,283942 & \\
Multiple R & 0,7133 & & \\
R square & 0,5237 & & \\
Adjusted R. Square & 0,4414 & & \\
Standart Error & 10,74542 & & \\
F. Ratio & 13,5156 & & \\
Durbin Watson Test & 1,6244 & & \\
\hline
\end{tabular}

Regression coefficient value of competence $r=0.592$ indicates that, assuming other variables constant, the increase of competence by 1 point will lead to increase performance of employees to 0.592 points. Coefficient of job satisfaction $\mathrm{r}=0.674$, means performance of employees is $67.4 \%$. Regression coefficient value of work discipline 0.336 indicates that increasing discipline by 1 point will lead to increased performance of employees to 0.336 points.

Table 1 also shows coefficient of determination $(\mathrm{R} 2)=0.5237$, meaning that variability factor of competencee, 
job satisfaction and discipline explains variability of changes in organizational effectiveness by $52.37 \%$ and the remaining $47.63 \%$ is caused by other variables not included in this model. Furthermore, prior to regression results are used as a predictor, symptoms multicollinearity, heteroscedasticity and autocorrelation are tested. The results of the calculations in Table 1 is used to see the value of t-arithmetic and t-table of each variable. See Table 2 for clarification.

Table 2.Summary of t-test results

\begin{tabular}{ccccc}
\hline Variable & T statistic & Sig. T (Prob) & T Table & Significance/No \\
\hline $\mathrm{X}_{1}$ & 3,868 & 0,0002 & $+/-2,014$ & Significant \\
$\mathrm{X}_{2}$ & 3,2839 & 0,0016 & $+/-2,014$ & Significant \\
$\mathrm{X}_{3}$ & $-2,098$ & $-0,0037$ & $+/-2,014$ & Significant \\
\hline
\end{tabular}

Form Table 2, it can be seen the value of $\mathrm{t}$ and a table of each independent variable as follows:

a. The $\mathrm{t}$-value of competence $\left(\mathrm{X}_{1}\right) \mathrm{t}=3.868$ is greater than $\mathrm{t}$-table 2.014 at $\mathrm{p}=0.00025$. It means Ho is refused and $\mathrm{H} 1$ is accepted; competence variable has a significant influence on performance of employee.

b. The $\mathrm{t}$-value of job satisfaction variable $\left(\mathrm{X}_{2}\right) \mathrm{t}=3.283$ is greater than $\mathrm{t}$-table 2.014 , at $\mathrm{p}=0.0016$. This means $\mathrm{Ho}$ is rejected and $\mathrm{H}_{1}$ is accepted; job satisfaction variables have a significant influence on performance of employee.

c. The $\mathrm{t}$-value for discipline $(\mathrm{X} 3) \mathrm{t}=1.028$ is smaller that $\mathrm{t}$-table $(2,014)$, at $\mathrm{p}=0.3070$. The probability value $\mathrm{r}=$ 0.3070 is greater that $(\mathrm{p}>0.05)$. It means Ho is accepted and $\mathrm{H} 1$ is rejected; discipline variable has a significant influence on performance of employee.

\subsection{Hypthesis Testing on the Effect of Simultaneous Independent Variables}

F-test is used to determine whether the three independent variables simultaneously have significant influences on the dependent variable. Table 3 shows that F-value $=15.53938$ is greater than F-table by 2.76 at $\propto=.05(95 \%$ confidence level), and level of significance of $\mathrm{F}=.005$. This means Ho is rejected and $\mathrm{H} 1$ is accepted. There is a significant effect posed by the competence, job satisfaction and discipline simultaneously on the performance of employees.

Table3.Summary of F-test

\begin{tabular}{cccccccc}
\hline Source & df & Sum of Square & Mean Square & F stat & Sig. F & F table & Remark \\
\hline Regression & 2 & 228840,49427 & 57210,12357 & 15,53938 & 0,000 & 2,76 & Significant \\
Residual & 16 & 276121,73631 & 3681,62315 & & & & \\
Total & 18 & 504962,23058 & 14891,74672 & & & & \\
\hline \multicolumn{2}{l}{ Multiple $\mathrm{R}=0,67319$} & R square $=0,45318$ & Adj R square $=0,4202$ & Std Error $=14,67638$
\end{tabular}

To see the effect of the independent variables together on the performance of employee, a multiple $\mathrm{R}$ is also used. Resut of $\mathrm{R}=0.453$ indicates that if there is a change in variation of three independent variables, there will affect employee performance variation on $45.3 \%$. In sum, variable of employee competencies, job satisfaction and work discipline all affect significantly partially or simultaneously on employee performance. Summary of contribution and interrelation among variables are shown in Figure 2.

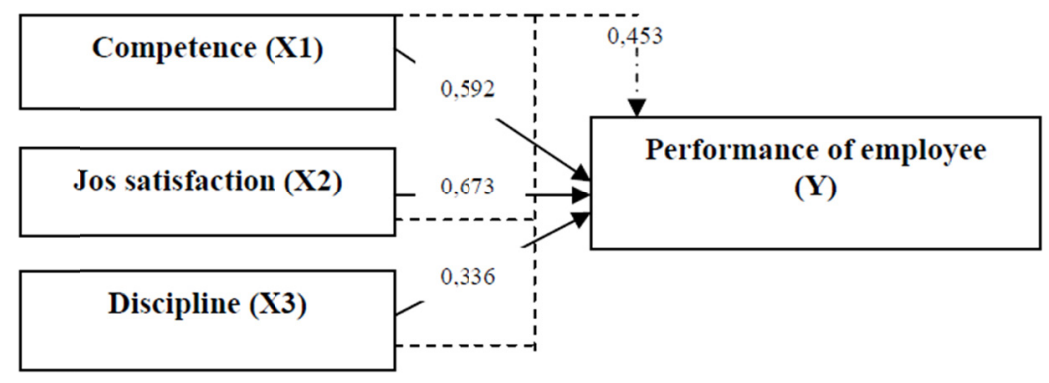

Figure 2. Relation of Inter-variables 


\section{Discussion}

Below we discuss the empirical relevance related to the effect of the employee competence, job satisfaction and work discipline on performance of employees in the Office of Women Empowerment and Family Planning of Fakfak West Papua.

\subsection{Competence of Employee}

Competence of the employee variable has a significant influence on the performance of employee. This can be seen by the result of hypotheis testing whose coefficients is below $5 \%$. As the hypothesis is proven, performance of employee can be improved when competence of employee, such as (1) education, (2) training, (3) experience is also enhanced.

The findings confirm that if better quality of the employee competence in the organization is achieved, the performance of emplyee will increase. However, the independent variable on the competence of employee identifies problem of inconsistencies between the educational background to position which is now held by the employees. This discrepancy can result in poor and less optimal performance of the employee. In addition, lack of opportunity given to employees to attend the education and training programs leads to the lack understanding of working procedures.

\subsection{Satisfaction of Employee}

Result of hypothesis testing shows that the significance of regression coefficients is below $5 \%$. As the hypothesis is proven, performance of employees can be enhanced when job satisfaction, such as (1) level of conformity salary with work, (2) level of welfare of employees (3) facilities for employees excel, (4) level of satisfaction with the office or employment and (5) giving employees opportunities for promotion are also enhanced.

Variable of job satisfaction that has a positive correlation but weak toward the performance of employees is variable of employee satisfaction. Result of Kendall's Tau correlation analysis $=0.241$, states that a positive correlation between the job satisfaction and the employee performance exists but weak. The positive correlation means that an increase in the employee satisfaction is believed to be able to improve the employee performance. Problems identified in this results include the inconsistencies of incentives for the employees and exprtise, and lack of facilities for the employees who excel.

\subsection{Discipline of Employee}

Work discipline variables have a significant influence on performance of employees. The result of hypothesis testing shows that the significance of regression coefficients is below $5 \%$. This means that the performance of employees can be improved if the discipline of work, such as (1) a low frequency delay into the office in a week, (2) do not leave workplace during working hours without permission from supervisors, (3) did not return early on a weekday, (4) timeliness of completion of work and (5) business execution of tasks in accordance with labor regulations is also improved.

Variable of the working discipline has a positive but weak correlation on the performance of meployee at .230. This means if discipline is increased, the performance will improve. Improved performance or achievements of one's work is determined by the increase level of discipline of the person concerned. Working discipline is related to how good a job assignment can be carried out in accordance with the timetable and resources that had been predetermined. Scheduling is intended as a means of control so that the work does not collide each other. With the control apparatus, a synergy between the work with other jobs exists, and the work produced meets standards of both quality and quantity.

This study supports the research by Haryanto (2005) and Ratnasari (2003) stating that the motivation and discipline have a positive and significant influence on the employee performance of staffs in Wonogiri Regional Employment Agency. The results also support findings of Suyitno' study (2008) admiting that the presence of attachment between the discipline and work facilities gives significant effect on work productivity of each employee of Department of Education in Malang.

\subsection{Competence, Job Satisfaction and Discipline of Employee}

The influence of the employee competence, job satisfaction and discipline toward the performance of employee is relatively low as seen from the coefficient of determination $47.5 \%$ or below $50 \%$. The relatively low performance can be inferred that other factors outside the research model present. Therefore, the need to explore other variables suspected of having links with employee performance is required.

Results of analysis shows that the minor hypothesis test results indicate that there are positive and significant correlations in each independent variable, they are: the job competence, job satisfaction and working discipline 
toward performance of employee. This result confirms the study of Robbins, admitting that performance is a function ofinteraction between competence, motivation and obsession, meaning that these three factors would interplay with each other to produce the performance.

The higher the competence, motivation and desire owned by an employee, there will be possible to create a high performance on the employee. As Porter and Lawler state the employee's job performance or achievements are supported by three factors: the employee motivation or effort, competence and clarity, and acceptance of the role. In addition, Wexley and Yukl argue the discipline is a factor that affects the performance. This study found that the major hypothesis obtained a positive relationship between the independent variables on the job competences, job satisfaction and discipline toward the performance of employees. This means that the three independent variables, i.e. job competencies, job satisfaction and discipline have a positive correlation on the performance of employees individually or jointly.

Of the three independent variables tested, the job competence variable gives the greatest relationship on the performance of employee at .682. This means the higher the level of competence of an employee, the person has a level of peak performance. On the contrary, the higher the person's level of competence but receives in appropriate or low income, his performance may decrease. In sum, the performance of an employee can be achieved optimally if it is supported and balanced with a high income.

\section{Conclusion}

This study attempts to identify the effects of the competence, job satisfaction, discipline on the performance of employees. Major findings showed that siginificant effects were proved between (1) competence to performance $(\mathrm{r}=0.628),(2)$ job satisfaction on performance $(\mathrm{r}=0.241)$, (3) discipline on performance $(\mathrm{r}=0230)$, and (4) equal relationship between competence, job satisfaction, discipline and performance of employees. No dominant variable appears in this study, each of which contributes $r=0.135(13,5 \%)$ showing a weak effect.

\section{References}

Alwi, S. (2002). Manajemen Sumber Daya Manusia, Strategi Keunggulan Kompetitif. Yogyakarta: BPFE

Anoraga, Pandji. (2001). Manajemen Bisnis. Cetakan Ketiga. Jakarta: Rineka Cipta.

Arikunto, S. (2002). Prosedur Penelitian: Suatu Pendekatan Praktek. Edisi revisi 5. Jakarta: PT Rineka Cipta.

As'ad, M. (2003). Psikologi Industri, Seri Ilmu Sumber Daya Manusia. Jakarta: Liberty.

Bernardin, John H dan Joyce A. Russel. (1998). Human Resource Management: An Experiental Approach. New Jersey: Mc Graw-Hill.

Cummings, W. K. (1984). Pendidikan dan Kualitas Manusia diJepang. Diterjemahkan Oleh Amin Soedoro. Yogyakarta: Gadjah Mada University Press.

Dwiyanto, A. (2003). Reformasi Tata Pemerintahan dan Otonomi Daerah, Cetakan Pertama, Yogyakarta: PSKK, Universitas Gajah Mada.

Gibson, L. J., Ivancevich, J. M., \&Donnelly, J. H.Jr. (1985). Organisasi: Perilaku, Struktur, Proses, Jakarta: PT Gelora Aksara Pratama.

Gie, T. L. (1995). Efisiensi Kerja bagi Pembangunan Negara: Suatu Bunga Rampai Bacaan, Yogyakarta: Gajah Mada University Press.

Gomes, F.C. (2002). Manajemen Sumber Daya Manusia. Yogyakarta: Andi Offset.

Handoko, H. T. (1984). Manajemen Personalia dan Sumber Daya Manusia. Yogyakarta: BPFE.

Haryono. (2009). Pengaruh Karakteristik Pekerjaan dan Kompensasi Terhadap kinerja Pegawai Dengan Motivasi Kerja Sebagai Variabel Intervening (Studi Pada Pegawai Badan Pelaksana Penyuluhan Pertanian, Perikanan dan Kehutanan Kabupaten Batang). Tesis, tidak terpublikasi

Hasan Ali Al-Zu'bi, (2010). A Study of Relationship between Organizational Justice and Job Satisfaction. International Journal of Business and Management, 5(12), 23-32. www.ccsenet.org/ijbm

Hasibuan,Melayu,SP. (2000). Manajemen Sumber Daya Manusia, Jakarta: Bumi Aksara.

Iqbal, A., Ijaz, M., Latif, F., \& Mushtaq. H. (2015). Factors Affecting the Employee's Performance: A Case Study of Banking Sector in Pakistan. European Journal of Business and Social Sciences, 4(8), 309-318. Retrieved from http://www.ejbss.com/recent.aspx-.

Irawan, P. (2000).Manajemen Sumber Daya Manusia. Jakarta: STIA-LAN Press. 
Kreitner \& Kinicki (2003). Perilaku Organisasi-diterjemahkan. Salemba Empat. Jakarta

Liliweri, A. (1997). Sosiologi Organisasi. Bandung: Citra Aditya Bakti.

Locke, E.A. (1969). The Natural and Causes of Job Satisfaction, Handbook of Industrial and Organizational Psychology. Chicago: Rand Mc Nally.

Luthans, F. (1995).Organizational Behavior. New York: Mc Grow Hill Inc.

Mangkunegara, A. A. Anwar Prabu. (2000). Manajemen Sumber Daya Manusia Perusahaan, Bandung: PT. Remaja Rosda Karya.

Manulang, M. L. (2004). Dasar-dasar Manajemen.Jakarta: Ghalia Indonesia.

Marshall, P. (2003). Mengapa Beberapa Orang Lebih Sukses Dari Yang Lainnya?. Manusia dan Kompetensi Panduan Praktis Untuk Keunggulan Bersaing. Editor Boulter, Murray Dalziel, dan Jackie Hill. Alih Bahasa. Bern. Hidayat. Jakarta: Penerbit PT Bhuana Ilmu Populer.

Martoyo,S. (2004). Manajemen Sumber Daya Manusia. Yogyakarta: BPFE.

Mayo, A. (2001). The Human Value of the Enterprise, Valuing People as Assets. London: Nicholas Brealey Pub

Muindi, F., \& K'Obonyo, P. (2015). Quality of Work Life, Personality, Job Satisfaction, Competence, and Job Performance: A Critical Review of Literature. European Scientific Journal, 11(26), 21-29.

Nawawi, H. H. (1992). Instrumen Penelitian Bidang Sosial. Yogyakarta: Gajah Mada Universitas Press

Nitisemito, A. S. (1995). Manajemen Personalia (Manajemen Sumber Daya Manusia). Jakarta: Ghalia Indonesia.

Porter, L.W. (1961). A Study of Perceived Need Satisfaction in Bottom and Middle Management Job. In Porter, D.E., and P.B. Applewhite. Studies in Organizational Behaviour and Management. New York: International Textbook Company.

Robbins, S.P.(1996).Perilaku Organisasi. Edisi Bahasa Indonesia,Jilid I dan II,Prinhalindo, Jakarta.

Rue, LW, LL Byars, (1980). Management: Theory and Application, New York: Ricard D. Irwin Inc, Homewood IL.

Simamora,H. (1995).Manajemen Sumber Daya Manusia. STIE YKPN,Jakarta.

Spencer, L. M. Jr., \& Spencer, M. S. (1993). Competence At Work Models for Superior Performance, United State of America. New Jersey: John Wiley \& Sons, Inc.

Steers, R. M. (1985). Efektivitas Organisasi. Diterjemahkan oleh Yamin, Magdalena. Jakarta: Erlangga.

Thaief, I., Baharuddin, A., Priyono, \& Idrus, M. S. (2015). Effect of Training, Compensation and Work Discipline against Employee Job Performance (Studies in the Office of PT. PLN (Persero) Service Area and Network Malang). Review of European Studies, 7(11), 21-30.

Wekley, Kenneth, N dan Yukl, Gary, terjemahan Muh Shobaruddin. (2000). Perilaku Organisasi dan Psikologi Personalia, Jakarta: Rineka Cipta.

Wood, Wallace, Zeffane, Schermerhorn, Hunt, \& Osborn. (2001). Organizational Behavior A Global Perspective. Sydney: John Wiley \&Sons.

Zaim, H., Yaşar, M. F., \& Ünal, Ö. F. (2013). Analyzing the Effects of Individual Competencies on Performance: A Field Study in Services Industries in Turkey. Journal of Global Strategic Management, 7(2), 67-77. DOI: 10.20460/JGSM.2013715668

\section{Copyrights}

Copyright for this article is retained by the author(s), with first publication rights granted to the journal.

This is an open-access article distributed under the terms and conditions of the Creative Commons Attribution license (http://creativecommons.org/licenses/by/4.0/). 